\title{
MENINGKATKAN MOTIVASI BELAJAR SISWA PADA SIMULASI DIGITAL MELALUI PENGGUNAAN EDMODO DI SEKOLAH MENENGAH KEJURUAN
}

\author{
Yuliana Endah Saputri ${ }^{1}$, Ismail ${ }^{2}$, Sri Mulyani ${ }^{3}$ \\ Program Studi Teknologi Pendidikan, Universitas Veteran Bangun Nusantara ${ }^{1,2,3}$ \\ Email: yendah702@gmail.com ${ }^{1}$
}

\begin{abstract}
Abstrak
Penelitian ini bertujuan untuk meningkatkan motivasi belajar dalam mata pelajaran simulasi digital melalui edmodo pada siswa kelas X SMK Tamansiswa Sukoharjo tahun ajaran 2017/2018. Jenis penelitian ini adalah Penelitian Tindakan Kelas (PTK). Kegiatan ini dilakukan selama dua siklus. Setiap siklus terdiri dari empat tahapan yaitu perencanaan, pelaksanaan, observasi, dan refleksi. Subjek penelitian ini adalah siswa kelas X SMK Tamansiswa Sukoharjo dengan jumlah 23 siswa. Metode pengumpulan data pada penelitian ini adalah menggunakan metode observasi, wawancara dan dokumentasi. Indikator keberhasilan dalam penelitian ini adalah ketuntasan belajar siswa sebesar $>70 \%$. Teknik analisis data yang digunakan dalam penelitian ini adalah teknik deskriptif kuantitatif. Hasil penelitian ini menunjukan adanya peningkatan motivasi belajar Simulasi Digital pada siswa kelas X SMK Tamansiswa. Kondisi awal prosentase ketuntasan hanya sebesar 34\%. Setelah dilakukan siklus I (satu) diperoleh hasil peningkatan motivasi belajar simulasi digital sebesar 57,6 \% dan pada siklus II diperoleh hasil prosentase sebesar 90,65\%. Peningkatan ini tentu dikarenakan adanya perbaikan-perbaikan selama proses pembelajaran oleh guru dan kolaborator selama pelaksanaan setiap siklus. Berdasarkan hasil penelitian tersebut maka dapat disimpulkan bahwa penggunaan edmodo secara tepat dapat meningkatkan motivasi belajar dalam mata pelajaran Simulasi Digital pada siswa kelas X SMK Tamansiswa.
\end{abstract}

Kata-kata kunci: Motivasi Belajar, Simulasi Digital, Edmodo

\section{IMPROVING STUDENT'S MOTIVATION IN LEARNING DIGITAL SIMULATIONS USING EDMODO AT VOCASIONAL HIGH SCHOOL}

\author{
Yuliana Endah Saputri ${ }^{1}$, Ismail ${ }^{2}$, Sri Mulyani $^{3}$ \\ Education Technology Study Program, Veterans University Bangun Nusantara ${ }^{1,2,3}$ \\ Email: yendah702@ gmail.com ${ }^{1}$
}

\begin{abstract}
This study aims to improve learning motivation in digital simulation subjects through edmodo on students of class X SMK Tamansiswa on academic year 2017/2018. This type of research is Classroom Action Research (CAR). This activity is done for two cycles. Each cycle consists of four stages: planning, execution, observation, and reflection. The subjects of this study are students of class X SMK Tamansiswa with the number of 23 students. Data collection method in this research is using observation method, interview and documentation. The indicator of success in this study is mastery learning students of $>70 \%$. Data analysis technique used in this research is quantitative descriptive technique. The results of this study indicate an increase in learning motivation Digital Simulation in students of class X SMK Tamansiswa. The initial condition of percentage mastery is only $34 \%$. After the cycle I (one) obtained the results of the increase in learning motivation of digital simulation of $57.6 \%$ and in cycle II obtained a percentage of $90.65 \%$. The increase is certainly due to improvements during the learning process by teachers and collaborators during the execution of each cycle. Based on the results of this study it can be concluded that the use of edmodo can precisely improve learning motivation in Digital Simulation subjects in students of class X SMK Tamansiswa.
\end{abstract}

Keywords: Learning Motivation, Digital Simulation, Edmodo 


\section{PENDAHULUAN}

Pendidikan merupakan faktor yang menentukan kesejahteraan manusia sehingga dapat digunakan sebagai indikator kemajuan suatu bangsa dan negara. Semakin tinggi kualitas pendidikan suatu bangsa dan negara maka dapat dipastikan semakin maju dan sejahtera bangsa dan negara tersebut. Oleh sebab itu, diperlukan perhatian khusus yang diajukan pada perkembangan dan kemajuan pendidikan guna meningkatkan mutu dan kualitas pendidikan.

Faktor pencapaian tujuan pendidikan melalui proses pembelajaran yaitu faktor dari guru dan motivasi siswa itu sendiri. Menurut Clayton Alderfer (Nashar, 2004: 42) Motivasi merupakan kecenderungan siswa dalam melakukan kegiatan belajar yang di dorong oleh hasrat untuk mencapai hasil dan tujuan tertentu. Apabila sesorang memiliki motivasi untuk belajar maka siswa tersebut dengan baik melakukan aktifitas belajar dan memiliki prestasi akademik yang lebih baik. Motivasi siswa dapat meningkatkan keinginan siswa belajar.

Motivasi belajar siswa kelas X SMK Tamansiswa Sukoharjo masih rendah. Pelaksanaan pembelajaran pada SMK Tamansiswa Sukoharjo masih menggunakan metode dan media seadanya. Kurangnya pemanfaatan media dalam proses pembelajaran membuat peserta didik kurang semangat dalam belajar sehingga motivasi belajar yang di dapat oleh peserta didik rendah.

Upaya yang dapat dilakukan oleh guru untuk meningkatkan motivasi belajar siswa adalah pembelajaran melalui Edmodo. Edmodo merupakan facebook untuk sekolah yang diperuntukkan untuk pendidik dan peserta didik. Edmodo merupakan cara untuk menciptakan proses pembelajaran yang efisien sehingga peserta didik termotivasi untuk belajar dan hasil belajar sesuai harapan pendidik. Penelitian ini bertujuan untuk meningkatkan motivasi belajar dalam mata pelajaran simulasi digital melalui edmodo pada siswa kelas $\mathrm{X}$ SMK Tamansiswa Sukoharjo tahun ajaran 2017/2018.

Menurut Hasibuan (Hasibuan, 2008) Motivasi adalah Pemberian daya penggerak yang menciptakan kegairahan kerja seseorang agar mereka mau bekerjasama, bekerja efektif dan terintegrasi dengan segala daya upayanya untuk mencapai kepuasan. Menurut Sutrisno (Sutrisno, 2011) Motivasi adalah suatu faktor yang mendorong seseorang untuk melakukan suatu aktifitas tertentu.

Motivasi belajar adalah dorongan internal dan eksternal pada siswa-siswi yang sedang belajar untuk mengadakan perubahan tingkah laku, pada umumnya, dengan beberapa indikator atau unsur yang mendukung (Hamzah B. Uno, 2007).Motivasi belajar dikemukakan oleh A.M. Sardiman (A.M Sardiman, 2007) 
yaitu keseluruhan daya penggerak dalam diri siswa yang menimbulkan kegiatan belajar dan menjamin kelangsungan kegiatan belajar, sehingga tujuan subyek belajar dapat tercapai.

Simulasi Digital adalah Mata Pelajaran yang membekali agar dapat mengomunikasikan gagasan atau konsep melalui media digital. Dalam proses pembelajaran, dapat mengomunikasikan gagasan atau konsep yang dikemukakan orang lain dan mewujudkannya melalui presentasi digital, dengan tujuan untuk menguasai teknik mengomunikasikan gagasan atau konsep.

Menurut Basori (Basori, 2013) menjelaskan Edmodo merupakan aplikasi yang menarik bagi guru dan siswa dengan elemen sosial yang menyerupai facebook. Edmodo ditujukan untuk penggunaan bagi guru,siswa dan orangtua siswa.Menurut Gatot dalam jurnal singgih dan Meini (Singgih \& Meini, 2014) Edmodo adalah platfrom media sosial yang sering di gambarkan sebagai facebook untuk sekolah. Dengan platfrom ini, seorang pengajar seperti dosen misalnya, lebih mudah untuk memonitor mahasiswanya.

Menurut Zwang dalam (Subiyantoro \& Ismail, 2017) jaringan pendidikan secara luas (global) yang fungsi utamanya membantu menghubungkan pebelajar atau peserta didik dengan orang dan atau sumber belajar yang dibutuhkan dalam rangka mencapai potensi diri. Edmodo memiliki beberapa keunggulan fasilitas diantaranya: 1) Pembuatan grup untuk masing-masing kelas dan subgrup untuk beberapa kelompok dalam kelas tersebut, 2) Pembuatan assignment, 2) Pembuatan Quis, 3) Penilaian, dan lain sebagainya. Sementara menurut Charles Wankel (2011) kelebihan edmodo adalah : 1) Mudah untuk mengirim berkas, gambar, video, dan link. 2) Mengirim pesan individu ke pengajar. 3) Membuat grup untuk diskusi tersendiri menurut kelas dan topik tertentu. 4) Lingkungan yang aman untuk peserta didik baru.

\section{METODE PENELITIAN}

Penelitian ini merupakan Classroom Action Research atau Penelitian Tindakan Kelas, selanjutnya disingkat PTK. Subiyantoro \& Mulyani (2017) menyebut PTK bertujuan untuk memperbaiki atau meningkatkan kualitas proses dan hasil pembelajaran. Prosedur pelaksanaan PTK meliputi: perencanaan, pelakasanaan tindakan, pengamatan, dan refleksi yang selalu dilakukan pada setiap siklusnya. Berikut adalah gambar prosedur penelitian PTK. 


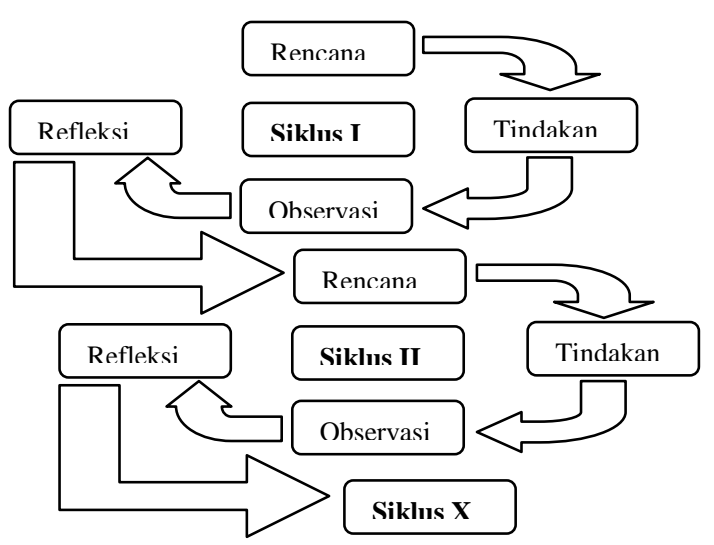

Gambar 1. Prosedur Penelitian PTK adopsi dari Kemmis and Taggart

Setiap siklus terdiri dari 4 tahapan, yaitu perencanaan, tindakan, observasi, dan refleksi. Sesuai dengan penjelasan Subiyantoro \& Mulyani (2017) pada tahap perencanaan, kegiatannya antara lain merumuskan spesifikasi sementara dalam meningkatkan motivasi belajar melalui edmodo, menyusun rencana pelaksanaan tindakan, membuat instrumen penelitian, membuat RPP dengan pembelajaran menggunakan multimedia interaktif, membuat lembar observasi untuk merekam aktifitas guru dan peserta didik dalam pembelajaran.

Pada tahap tindakan, setelah diperoleh gambaran kelas, keadaan peserta didik dan sarana belajar, maka dilakukan tindakan dengan memanfaatkan edmodo sebagai media pembelajaran siswa. Pada tahap observasi, dilakukan pengamatan terhadap pelaksanaan tindakan dengan menggunakan lembar observasi yang telah disiapkan sebelumnya guna mencatat aktivitas guru dan siswa. Sementara tahap refleksi digunakan untuk mengukur keberhasilan suatu siklus dan dilakukan pada setiap akhir siklus. Kegiatan ini untuk melihat keberhasilan dan kelemahan dari perencanaan yang dilaksanakan sebelumnya. Subiyantoro \& Mulyani (2017) juga mengatakan refleksi menjadi acuan dalam menentukan perbaikan atas kelemahan pelaksanaan siklus sebelumnya untuk diterapkan pada siklus selanjutnya.

Pada penelitian ini, populasi penelitian adalah seluruh siswa di kelas X SMK Tamansiswa Sukoharjo. Sementara sampel yang diambil hanyalah 1 kelas yang memiliki rata-rata motivasi belajar rendah. Teknik sampling yang digunakan dalam penelitian ini adalah Sampling Purposive, yaitu teknik penentuan sampel dengan pertimbangan tertentu. Pada penelitian ini pertimbangan yang digunakan adalah berdasarkan hasil lembar observasi yang menunjukkan rata-rata motivasi belajar siswa rendah.

Berdasarkan pendekatan dan model penelitian yang dipilih serta situasi dan kondisi lapangan yang dijadikan objek dalam penelitian, maka metode pengumpulan data yang digunakan berupa metode non tes. Instrumen yang digunakan diantaranya lembar observasi, dan pedoman wawancara. Penelitian ini menggunakan teknik pengumpulan data observasi,wawancara dan dokumentasi. 
Observasi yang dilaksanakan oleh peneliti dalam penelitian ini adalah bersifat langsung. Secara langsung peneliti mengamati aktivitas belajar yang dilaksanakan siswa siklus I dan siklus II. Lembar observasi digunakan untuk mengamati antara lain pelaksanaan tindakan, aktifitas belajar peserta didik, serta suasana dan kelancaran belajar. Tujuan pengamatan ini adalah untuk mengetahui kekurangtepatan pelaksanaan tindakan.

Hasil observasi tersebut digunakan sebagai bahan diskusi antara peneliti dan kolabolator pada tahap refleksi dan selanjutnya dijadikan sebagai dasar untuk melakukan perbaikan dan perencanaan siklus berikutnya. Pedoman wawancara digunakan untuk acuan dalam melakukan wawancara terhadap siswa yang memiliki motivasi tinggi dan rendah, serta untuk mengetahui respon siswa terhadap metode pembelajaran yang diterapkan. Penelitian ini dikatakan berhasil dan dapat dihentikan apabila beberapa kriteria yang telah ditentukan telah tercapai. Dokumentasi Teknik ini digunakan untuk mencari tahu kondisi awal peserta didik. Pada kondisi awal siswa mendengarkan guru dengan baik atau tidak dan motivasi siwa tersebut rendah atau tinggi. Untuk mengukur ketercapaian tujuan penelitian dirumuskan indikator bahwa $70 \%$ siswa menunjukan peningkatan motivasi belajar Simulasi
Digital kelas X SMK Tamansiswa Sukoharjo.

\section{HASIL DAN PEMBAHASAN}

Belajar adalah serangkaian kegiatan jiwa dan raga untuk memperoleh suatu perubahan tingkah laku sebagai hasil dari pengalaman individu dalam interaksi dengan lingkungannya yang menyangkut kognitif, afektif, dan psikomotor.

Faktor pencapaian tujuan pendidikan melalui proses pembelajaran yaitu faktor dari guru dan motivasi siswa itu sendiri. Menurut Clayton Alderfer (Nashar, 2004: 42) Motivasi merupakan kecenderungan siswa dalam melakukan kegiatan belajar yang di dorong oleh hasrat untuk mencapai hasil dan tujuan tertentu. Apabila sesorang memiliki motivasi untuk belajar maka siswa tersebut dengan baik melakukan aktifitas belajar dan memiliki prestasi akademik yang lebih baik. Motivasi siswa dapat meningkatkan keinginan siswa belajar

Motivasi belajar adalah dorongan internal dan eksternal pada siswa-siswi yang sedang belajar untuk mengadakan perubahan tingkah laku, pada umumnya, dengan beberapa indikator atau unsur yang mendukung (Hamzah B. Uno, 2007).Motivasi belajar dikemukakan oleh A.M. Sardiman (A.M Sardiman, 2007) yaitu keseluruhan daya penggerak dalam diri siswa yang menimbulkan kegiatan belajar dan menjamin kelangsungan 
kegiatan belajar, sehingga tujuan subyek belajar dapat tercapai.

Simulasi Digital adalah Mata Pelajaran yang membekali agar dapat mengomunikasikan gagasan atau konsep melalui media digital. Dalam proses pembelajaran, dapat mengomunikasikan gagasan atau konsep yang dikemukakan orang lain dan mewujudkannya melalui presentasi digital, dengan tujuan untuk menguasai teknik mengomunikasikan gagasan atau konsep.

Menurut Basori (Basori, 2013) menjelaskan Edmodo merupakan aplikasi yang menarik bagi guru dan siswa dengan elemen sosial yang menyerupai facebook. Edmodo ditujukan untuk penggunaan bagi guru,siswa dan orangtua siswa.Menurut Gatot dalam jurnal singgih dan Meini (Singgih dan Meini, 2014) Edmodo adalah platfrom media sosial yang sering di gambarkan sebagai facebook untuk sekolah. Dengan platfrom ini, seorang pengajar seperti dosen misalnya, lebih mudah untuk memonitor mahasiswanya.

Pada kondisi awal pembelajaran Simulasi Digital ada beberapa siswa yang suka berbincang dengan teman sendiri dan juga ada siswa yang bermain - main sendiri. Aktivitas atau perilaku belajar seperti itu membuat siswa tidak memperhatikan dengan baik apa yang disampaikan oleh guru. Sehingga siswa tidak dapat memperhatikan pelajaran dengan baik dan siswa lain banyak yang mengikuti siswa tersebut sehingga menciptakan kegaduhan di dalam kelas. Hal tersebut berimbas pada motivasi belajar siswa pada mata pelajaran Simulasi Digital yang dicapai menjadi di bawah $70 \%$. Dengan keadaan yang seperti itu maka diterapkanlah edmodo didalam pembelajaran Simulasi Digital dengan harapan dapat meningkatkan motivasi belajar siswa.

Pada siklus I penerapan edmodo dalam pembelajaran simulasi digital sudah ada sedikit peningkatan aktifitas belajar meskipun belum signifikan. Pada saat berdo'a bersama masih ada siswa yang belum khidmad dalam melaksanakannya. Selain itu masih ada siswa yang berbincang - bincang dengan siswa lain dan juga masih ada siswa yang bermain - main sendiri. Pada saat pembelajaran masuk dalam kegiatan inti siswa sudah cukup mampu melakukan apa yang dikehendaki guru melalui kuis lisan yang diajukan akan tetapi masih ada siswa yang belum bisa menjawab pertanyaan bahkan malah bercanda dalam menjawabnya. Dari hasil observasi motivasi pembelajaran melalui edmodo, ada 4 siswa yang belum dapat mengikuti pembelajaran dengan baik.Dari data motivasi belajar siswa kelas kelas X SMK Tamansiswa Sukoharjo pada siklus I prosentase motivasi siswa baru mencapai $57,6 \%$ sehingga belum mencapai Indikator keberhasilan $\geq 70 \%$.

Pada siklus II penerapan edmodo pada kegiatan belajar ada tindakan tambahan 
yang diterapkan untuk memperbaiki hal hal yang kurang dari siklus I. Sebelum do'a dimulai guru memfokuskan siswa terlebih dahulu agar siswa menjalankan do'a bersama dengan penuh khidmad. Perhatian siswa difokuskan agar siswa mendengarkan dan memperhatikan guru dalam memberikan penjelasan mengenai kegiatan yang akan dilaksanakan. Mayoritas tindakan tambahan yang diberikan pada siklus II tersebut terbukti berhasil meningkatkan aktifitas belajar siswa, karena siklus II ini merupakan tahap untuk lebih mengoptimalkan penerapan edmodo pada pembelajaran Simulasi Digital (Simdig) siswa kelas X SMK Tamansiswa Sukoharjo, yaitu mengoptimalkan tindakan - tindakan pada siklus I yang sudah mampu meningkatkan motivasi belajar siswa walaupun belum terlihat signifikan. Selain itu juga memberikan tindakan lanjut agar siswa antusias untuk bertanya pada saat diberi kesempatan bertanya. Dari hasil obserasi menunjukan peningkatan motivasi siswa,sehingga dapat mencapai lebih dari $70 \%$.Dengan prosentase ketuntasan 90,65\% yang sudah berada di atas indikator keberbasilan $\geq 70 \%$.

Tabel 1. Rangkuman Hasil Tindakan

\begin{tabular}{llllll}
\hline \multirow{2}{*}{ No. } & Kriteria & Target & Pra Siklus & Siklus I & Siklus II \\
& & $\%$ & $\%$ & $\%$ & $\%$ \\
\hline 1. & Motivasi Belajar & $\geq 70$ & 34 & 57,6 & 90,65 \\
\hline
\end{tabular}

Berdasarkan rangkuman hasil penelitian terlihat jelas bahwa penggunaan edmodo secara tepat dapat meningkatkan motivasi belajar siswa. Hasil penelitian ini sesuai dengan hasil penelitian yang dilakukan oleh Fauziyah Sulistiani (2016) bahwa pembelajaran melalui edmodo terbukti dapat meningkatkan motivasi belajar siswa. Hasil yang diperoleh pada siklus I yaitu sebesar 74,22\%, kemudian pada siklus II mengalami peningkatan yaitu $81,09 \%$. Pada penelitian ini, terpantau siswa menjadi lebih fokus dengan pembelajaran, suasana lebih kondusif dan santai. Kondisi inilah yang diharapkan sehingga pembelajaran berjalan efektif, efisien dan berdaya tarik.

Perbaikan proses pembelajaran yang dilakukan melalui tindakan-tindakan pada Siklus I dan Siklus II menyebabkan beberapa aspek mengalami peningkatan, seperti motivasi belajar siswa, aktivitas siswa dan aktivitas guru. Berdasarkan rangkuman hasil penelitian, maka dapat dikatakan penggunaan edmodo secara tepat dapat digunakan untuk meningkatkan motivasi belajar siswa. Harapannya, setelah aktivitas siswa meningkat, motivasi belajar juga ikut meningkat. Sesuai dengan hasil penelitian Fauziyah Sulistiani (2016) dimana siswa yang mengikuti proses 
pembelajaran dengan penggunaan edmodo secara tepat, motivasi belajarnya lebih baik dengan perbedaan cukup signifikan dibandingkan siswa dengan pembelajaran tidak menggunakan edmodo. Ia juga menambahkan bahwa edmodo cocok digunakan untuk semua sekolah, terutama untuk sekolah yang menggunakan kurikulum 2013.

\section{KESIMPULAN DAN SARAN}

Berdasarkan hasil penelitian didapatkan data pada kondisi awal kelas $\mathrm{X}$ SMK Tamansiswa Sukoharjo memiliki aktivitas belajar kurang baik dalam mengikuti pembelajaran Simulasi Digital (Simdig). Kurang baiknya aktifitas belajar tersebut mempengaruhi motivasi belajar siswa. Hingga pada kondisi awal tersebut belum dapat mencapai indikator keberhasilan dalam penelitian tindak kelas ini, yaitu $70 \%$.

Penerapan Edmodo adalah cara yang tepat untuk mengoptimalkan aktivitas belajar siswa,hingga meningkatkan motivasi belajar siswa. Agar penerapan edmodo dalam rangka mengaktifkan siswa dan meningkatkan motivasi belajar siswa dapat berjalan dengan maksimal maka dalam pelaksanaanya guru selalu berusaha mengkondisikan siswa untuk selalu memiliki motivasi belajar tinggi, memahami tujuan pembelajaran yang akan dilaksanakan, mampu mengidentifikasi alat yang digunakan dalam kegiatan, mampu melaksanakan kegiatan pembelajaran dengan baik serta mampu mengungkapkan pendapat dan pertanyaan - pertanyaan.

Peningkatan aktifitas belajar siswa pada penerapan edmodo terbukti berhasil meningkatkan motivasi belajar Simulasi Digital (Simdig) pada siswa kelas X SMK Tamansiswa Sukoharjo. Pada akhir siklus II penerapan edmodo diperoleh motivasi belajar siswa yang meningkat yaitu mencapai keberhasilan sebanyak 90,65\%.

Berdasakan penjelasan di atas, maka penerapan edmodo yang optimal dengan mengaktifkan siswa semaksimal mungkin dapat meningkatkan motivasi belajar mata pelajaran Simulasi Digital (Simdig) pada siswa kelas X SMK Tamansiswa Sukoharjo tahun pelajaran 2017/2018.

Meskipun pemanfaatan edmodo mampu meningkatkan motivasi belajar siswa kelas X Tamansiswa Sukoharjo, bukan berarti hasil penelitian ini dapat digeneralisasikan pada kelas atau mata pelajaran lainnya. Dasar pemilihan media pembelajaran bukanlah kecanggihan, tetapi keefektifan, efisiensi dan daya tarik bagi siswa. Oleh karena itu, sebagai seorang guru pandai-pandailah dalam memilih media yang tepat, dan variasikan penggunaan media agar semua gaya belajar siswa dapat tercover. 


\section{DAFTAR PUSTAKA}

Basori. 2013. "Pemanfaatan Social Learning Network Edmodo dalam Membantu Perkuliahan Teori Bodi Otomotif di Prodi PTM JPTK FKIP UNS”. JIPTEK. Vol.6 No.21

Hasibuan. 2008. Manajemen Sumber Daya Manusia. Jakarta: Bumi Aksara

Ismail. 2011. Penelitian Pendidikan (Suatu pengantar). Sukoharjo: Univet Bantara Press

Ismail, Bambang T. 2011. Pedoman Menulis Skripsi (Edisi Revisi). Sukoharjo: Univet Bantara Press

Nashar. 2004. Peranan Motivasi dan Kemampuan Awal dalam Kegiatan Pembelajaran. Jakarta: Delia Press

Singgih, Meini. 2014. "Pengembangan Media Pemelajaran E-Learning Berbasis Edmodo Pada Kompetensi Dasar Menerapkan Konsep Dasar Sistem Komunikasi Data Sinyal Digital Melalui Media Kabel Fiber dan Frekuensi Radio di SMK N 1 Jetis Mojokerto". E-Journal UNESA. Vol.3, No.2

Subiyantoro, S., \& Ismail. (2017). DAMPAK LEARNING MANAGEMENT SYSTEM
(LMS) PADA PERFORMA AKADEMIK MAHASISWA DI PERGURUAN TINGGI. Edudikara: Jurnal Pendidikan Dan Pembelajaran, 2(4), 307-314.

Subiyantoro, S., \& Mulyani, S. (2017). KEGUNAAN MULTIMEDIA INTERAKTIF DALAM PEMBELAJARAN BAHASA INGGRIS. Edudikara: Jurnal Pendidikan Dan Pembelajaran, 2(2), 92-100.

Sulistiani, Fauziyah. 2016. Implementasi Model Pembelajaran Blended Learning Berbasis Edmodo Untuk Meningkatkan Motivasi dan Prestasi Belajar Siswa Kelas X AK2 SMK N 7 Yogyakarta Tahun Ajaran 2015/2016.Pendidikan

Akuntansi.Fakultas Ekonomi.UNY

Sutrisno. 2010. Manajemen Sumber Daya Manusia. Jakarta: Prenada Media Group

Uno, Hamzah B. 2007. Model Pembelajaran Menciptakan Proses Belajar Mengajar yang Kreatif dan Efektif. Jakarta: Bumi Aksara

Uno, Hamzah B. 2014. Teknologi Komunikasi dan Informasi Pembelajaran . Jakarta: Bumi Aksara 